\title{
Islamic Revivalism in Recent Western Writings
}

This article revolves around certain presuppositions, themes, and theories related to a selected number of western writings on Islamic resurgence in the modern Arab world. In this regard, I purport to examine the following claims: 1) Islamic resurgence is a widespread traditional, cultural, and political phenomenon in modern Islam; 2) some western (and even Muslim) studies of Islamic resurgence have touched only the surface and, therefore, their methodological orientation has been inadequate; 3) as a facet of modern Islam, Islamic resurgence has reinterpreted the Islamic tradition in a creative and unique way; and 4) although the major leaders of the Islamic movement have placed philosophy outside the pale of Islam, one is tempted to study Islamic resurgence as a philosophical expression of modern and contemporary Muslim societies. ${ }^{1}$

In order to show the theoretical inadequacy of the writings on Islamic revivalism, I would like to discuss four recently published studies: Emmanuel Sivan, Radical Islam: Medieval Theology and Modern Politics $^{2}$; W. Montgomery Watt, Islamic Fundamentalism and Modernity ${ }^{3}$; Leonard Binder, Islamic Liberalism: A Critique of Development Ideologies $^{4}$; and Ronald Nettler, Past Trials and Present Tribulations. ${ }^{5}$

In Radical Islam, Sivan proposes the following two ideas: First, to have a better understanding of the thinking of modern Islamic resurgence, especially that of Sayyid Qutb, ${ }^{6}$ one has to study the influence exerted

'Sayyid Qutb criticizes philosophy in general and argues that it lacks inspiration and a sense of praxis: "We must make it clear, however, that we do not desire to seek the truth of the Islamic concept merely for the sake of academic knowledge. We have no desire to add still another book to the shelves of Islamic libraries under the heading of "Islamic philosophy." Sayyid Qutb, The Islamic Concept and Its Characteristics, trans. Mohammed M. Siddiqui (Indianapolis: American Trust Publications, 1991), 5.

${ }^{2}$ New Haven: Yale University Press, 1990.

${ }^{3}$ London and New York: Routledge, 1988.

${ }^{4}$ Chicago: University of Chicago Press, 1988.

${ }^{5}$ New York: Pergamon Press, 1987.

${ }^{6}$ See the author's recent article on Sayyid Qutb: Ibrahim M. Abu-Rabi", "Discourse, Power, and Ideology in Modern Islamic Revivalism." The Muslim World, 81, nos. 3-4 (July-October 1991): 283-98. 
on Qutb's language and thought by Ibn Taymiyah (d. 1328) and Abu al A'la al Mawdudi (d. 1979). Second, Islamic revival is basically defensive and antimodern. In addition, the modernity-jähiliyah polarity (read as modernity-tradition polarity) provides the most adequate approach to study the dynamics of modem Islam. ${ }^{?}$

Sivan takes a political-theological approach in his discussion of the history of Arab societies during the past three decades. In other words, his objective is to analyze the connection between "political Islam" and society in selected Arab countries, especially Egypt, Lebanon, Syria, and Jordan. In my opinion, the book is highly reductionist and selective and does not portray adequately the historical dynamics between religious institutions, ideas, and personalities on the one hand and Arab society on the other. Sivan uses a variety of terms to refer to the phenomenon of Islamism: radical Islam (p. 1), Islamic revival (p. 3), Islamic militancy (p. 11), and fundamentalism (p. 67).

In the first chapter, "The Mood: Doom and Gloom," Sivan asserts that Muslim "fundamentalists" are a pessimistic group of people because they abhor current social and political realities. This aversion to reality has translated itself into a radical political movement that aims at restructuring the status quo. Thus, Sivan reduces Islamism to mere politics:

Islamic revival-while activist and militant-is thus essentially defensive; a sort of holding operation against modernity. And though it has no doubt a sharp political edge, it is primarily a cultural phenomenon. Its very strength proceeds from this alliance of political and cultural protest. (p. 3)

As is common in western writing on Islam, the term "modernity" is used often. Sivan says that western modernity, ${ }^{8}$ in its economic and intellectual dimensions, presents a special challenge to Muslims: "Western investment means the integration of the Islamic world into the system of the multinationals, which is totally alien to Muslim concepts of interests,

${ }^{7}$ Many scholars follow this approach during their investigation of Islamic resurgence. See: Issa Boullata, Trends and Issues in Modern Arab Thought (Albany: State University of New York Press, 1990); Gilles Keel, The Revenge of God: The Resurgence of Islam, Christianity and Judaism in the Modern World (Cambridge: Polity Press, 1994); and Abdallah Labdaoui, Les nouveaus intellectuels arabe (Paris: L'Harmattan, 1993).

${ }^{8}$ On modernity, consult the following: Marshall Berman, All That Is Solid Melts into Air: The Experience of Modernity (New York: Simon and Schuster, 1982) and Anthony Giddens, The Consequences of Modernity (Stanford: Stanford University Press, 1990). 
insurance, taxation, and so on" (p. 10). Then he offers a major conclusion without providing enough historical evidence and introduction: "Islam thus comes out badly bruised from the encounter with modernity" (p. 14).

In my opinion, the author fails to provide an adequate historical analysis that takes into account the problematic of colonization in the Muslim world in its different manifestations: military, economic, cultural, political, religious, and conceptual. ${ }^{9}$ Sivan does not consider colonization to be a problematic at all. In his view, it is the Muslim rejection of modemity that is the crux of the matter:

The picture that emerges is not one which scholars studying Islamic society would tend to refute. Modernity has indeed made important gains, especially in recent decades. Islam, although more resilient than other traditional cultures, has seen its position greatly eroded. (p. 15)

The second study is W. Montgomery Watt's Islamic Fundamentalism and Modernity. In this book, Watt argues that the traditional Islamic worldview is incompatible with the conditions and demands of western modernity. ${ }^{10} \mathrm{He}$ contends that the modern Muslim mind is still determined by the epistemological rules of the early phase of Islam-what Mohammed Arkoun might call the classical Islamic phase. ${ }^{11}$

Watt offers only a quasitheoretical reading of the subject of Islam and modernity. Although modernity is one of his key analytic concepts, he does not define it clearly or portray adequately the dynamics of western hegemony over the Muslim world and its current consequences. The author further maintains that the traditional Islamic outlook, which was formed in the early phase of Islam against the background of the Qur'an, hadith, and consensus, is based on the following premises: the unchanging nature of the world, the finality and superiority of Islam, and the idealization of Muhammad as the perfect model that Muslims must follow. In reconstructing the epistemological foundations of this outlook,

'Khurshid Ahmad, a contemporary Islamic thinker, insists that colonialism is the single most important factor in the metamorphosis of modern Muslim societies. See Ibrahim M. Abu-Rabi`, ed., Islamic Resurgence: Challenges, Direction, and Future Perspectives: A Roundtable with Khurshid Ahmad (Tampa: The World and Islam Studies Enterprise, 1994), especially chapter three.

${ }^{10} \mathrm{~W}$. Montgomery Watt, Islamic Fundamentalism and Modernity (London and New York: Routledge, 1988).

${ }^{11}$ Mohammed Arkoun, Essais sur la Pensee islamique (Paris: Maisonneuve \& Larose, 1984), especially chapter eight. 
Watt argues quite explicitly that there is no place in Muslim thinking for development or for social and economic progress and advancement. $\mathrm{He}$ justifies the above view by saying that

apart from the particular dangers inherent in the idealization of early Islam, there is a general danger, namely, that the community becomes so obsessed with recreating something past that it fails to see and deal with the real challenges and problems of the present. (p. 22)

It is clear that Watt treats the complex and rich history of Islamic epistemology in a monolithic fashion. He is far less successful in his attempt at the reconstruction of the Islamic theory of knowledge than, let us say, both Fazlur Rahman ${ }^{12}$ and Mohammed Arkoun, to whom he refers quite often.

As for "religious revivalism," Watt argues that Islamic resurgence has resulted from the "ulama's desire to enhance their power and social prestige (p. 43). This thesis, in my opinion, misrepresents the formation and growth of modern Islamic movements, which should be understood, to a large extent, as a reaction to the western colonization of the Muslim world. Although he declares that one of the great evils of the present day is "the unscrupulous exploitation of the Third World by western multinational corporations" (p. 102), he does not show how this exploitation has affected the formation of the whole process of Islamic resurgence.

Watt's endeavor to present a true picture of the conflict between Islam and modernity is highlighted by his failure to grasp the complex composition of Islamic epistemology and its successive transformations through the system of the Shari'ah (Islamic law). He argues, for instance, that the traditional Islamic image "is making it difficult for Muslims to adjust adequately to life at the end of the twentieth century" (p. 71). Is it not the role of theology in any religious system to constantly adapt its main presuppositions to the exigencies of the changing world?

In conclusion, Watt fails to integrate the historical reality of the western exploitation of the Muslim world into a coherent system of analysis. At times, his analysis takes a highly descriptive form that lacks a dynamic reflection on the process of modern history. Furthermore, as indicated above, Watt's approach incorporates the idea of the superiority

${ }^{12}$ See Fazlur Rahman, Islam and Modernity: Transformation of an Intellectual Tradition (Chicago: University of Chicago Press, 1982) and Akbar Ahmed, Postmodernism and Islam (London: Routledge Press, 1992). 
of western culture over Islamic culture. It is time for Third World thinkers to take a critical stand towards this legacy of the West, westernization, and modemization in the Muslim world.

Leonard Binder's Islamic Liberalism: A Critique of Development Ideologies is the most sophisticated western study of the relationship between Islam and society in the modern Arab world to appear in the United States recently. Binder maintains that liberalism is not only rational, universal, and politically feasible, but that it is the only alternative to the political and moral predicament of the Third World, especially the Muslim world.

Binder claims that his main goal in writing on "Islamic liberalism" is to help Muslim intellectuals produce "à liberal Islamic discursive formation which poses a challenge to the existing scripturalist and fundamentalist alternatives." Modern Muslim theologians and thinkers are aware of the Straussian distinction between political philosophy and political theology. According to Leo Strauss, ${ }^{13}$ political theology is made up of those teachings that are based on divine revelation, whereas political philosophy is limited to what is accessible to the unassisted human mind. Westem political philosophy rejects any divine intervention in the historical and political process. Political philosophy, as advanced by Binder, is based on the idea that a democracy is the best context for political action. Therefore, according to this view, the main assumptions, trends, and manifestations of political philosophy are sustained by a democracy.

Binder contends that liberalism, as a political philosophy and western ideological formation, is viable in the contemporary Muslim world, especially in the Middle East. He points out that

political liberalism can exist only where and when its social and intellectual prerequisites exist .... These preconditions already exist in the Middle East." ${ }^{14}$

Political liberalism rests on the fundamental assumption of the state-religion separation. Although the latter has been a de facto reality in many Middle East societies for some time, Muslim theorists of contemporary state and politics still have not appropriated it.

\footnotetext{
${ }^{13}$ See Leo Strauss, What is Political Philosophy? (Chicago: University of Chicago Press, 1988).

${ }^{14}$ Leonard Binder, Islamic Liberalism: A Critique of Development Ideologies (Chicago: University of Chicago Press, 1988), 102.
} 
Clearly, Binder does not question the inherent notions of superiority underlying modernization theories. $\mathrm{He}$ argues that modernization theory is only "an academic transfer of the dominant, and ideologically significant paradigm employed in research on the American political system." Classical as well as contemporary American modemization theories have begun to take into account the importance of Islam as a cultural system and an ideological social phenomenon only recently. For a long time, the only factors considered were education, urbanization, media exposure, and economic productivity. As a result, modemization theorists, including Binder, have failed to present an adequate formulation of the relationship between Islam and society in the postcolonial phase. In one sense, Binder "atomizes" ${ }^{15}$ Islam to such an extent that he holds the comfortable notion that "Islam in its various forms, and categories, and applications, is only a part of Middle East culture, and by itself accounts for little." Such an inaccurate statement makes one doubt the coherence and vitality of any "liberal project" in an Islamic context.

Another of Binder's implicit assumptions is that western liberalism has been a major cause behind the transition of the modern Arab world from "a closed society" to "an open society." He contends, along the same lines as the famous "open society" theoretician Karl Popper, ${ }^{16}$ that the main characteristics of a "closed society" are defined by its organic ties, tribal and collectivist mentality, lack of individuality, and religious rigidity. The open (liberal) society, on the other hand, is marked by individuality, freedom of expression, rationalism, social mobility, and a critical appraisal of social reality. In other words, according to Binder, liberalism has assisted modern Arab society in maintaining a degree of tolerance and openness to outside influences.

Furthermore, the transition from a "closed" to an "open" society signals a total breakdown of tribalism and religious rigidity. Thus, for Binder, any reaction against liberalism in the modern Arab world, either in the form of "Islamic fundamentalism" or antiwestern nationalism, is, in fact, a reaction against social and economic progress and the scientific culture of western civilization. Therefore, one can theorize that Binder's political project for the Muslim Middle East is superimposed from the outside, since it fails to express the aspirations of Muslims as people.

${ }^{15}$ In one of his major studies on modern Islam, Hamilton Gibb argues that the Arab-Islamic mind is atomistic. Consult Hamilton Gibb, Modern Trends in Islam (Chicago: University of Chicago Press, 1947), especially chapter 1.

${ }^{16} \mathrm{Karl}$ Popper, The Open Society and Its Enemies, 2 vols. (Princeton: Princeton University Press, 1962). 
The fourth book is by the Canadian scholar Ronald Nettler. In Past Trials and Present Tribulations, ${ }^{17}$ Nettler's objective is to portray the Islamic doctrinal dimension of Muslim-Jewish relations. He argues that Muslims have developed a sophisticated and rich doctrine of hatred for Jews (including modern-day Israelis) since Muhammad founded the first Islamic state. Of course, his assumptions are bounded by an interest, context, and subjectivity. It seems that his objective is, in essence, to justify Israel's hegemonic and colonialist nature. As his context is that of Israeli scholarship, which is antagonistic to both Arabism and Islam, his personal interest would be to show that the real problem is not between Christendom (Europe) and Judaism, but between Islam and Judaism.

Nettler does not draw any analytical distinction between Judaism, Zionism, and Israel. ${ }^{18} \mathrm{He}$ considers Zionism to be the product of Judaism and Israel the culmination of both. Understood in this light, if Muslims oppose the Israeli occupation of Palestine, they oppose both Zionism and Judaism. It is this contention of many specialists on Jewish history that Zionism and the Jewish Holocaust have to be understood against the social, economic, political, and nationalist chauvinistic European background of the nineteenth and early twentieth centuries. ${ }^{19}$ The European persecution of the Jews not only culminated in the Holocaust but also in the creation of Israel. The writer is oblivious to this significant historical phenomena and, instead, considers the West to be the true liberator of the Jews when it supported the creation of the state of Israel.

It is clear that Nettler cannot see the anomalous consequence that the creation of Israel has brought upon Palestinian society: its total disintegration and the dispersal of its people. Instead, he discusses the alleged "darker side of Jewish life under Islam, which redefined the erstwhile conception of Islamic 'toleration' as having been more problematic than could before have been imagined" (p. ix). With no historical evidence in

${ }^{17}$ Ronald L. Nettler, Past Trials and Present Tribulations: Muslim Fundamentalists' View of the Jews (New York: Published for the Vidal Sasoon International Center for the Study of Anti-Semitism, The Hebrew University of Jerusalem by Pergamon Press, 1987).

${ }^{18}$ One of the best books on the subject is Benjamin Bei-Hallahmi, Original Sins: Reflections on the History of Zionism and Israel (New York: Olive Branch Press, 1993), especially chapter 4 .

${ }^{19}$ In this regard, see the following books by Marc H. Ellis: Ending Auschwitz: The Future of Jewish and Christian Life (Louisville: Westminster/John Knox Press, 1994); Toward a Jewish Theology of Liberation (Maryknoll: Orbis Books, 1988); Beyond Innocence and Redemption: Confronting the Holocaust and Israeli Power (New York: Harper and Row, 1990); and Isma'il Raji al Faruqi, Islam and the Problem of Israel (Islamic Council of Europe, 1990). 
hand, Nettler rushes to prove the "evil Muslim treatment of the Jews." ${ }^{20}$

Nettler aims at proving his thesis of "Muslim animosity to Jews" by treating some of the works of the leading Egyptian Muslim thinker, Sayyid Qutb (d. 1966). He accepts uncritically the argument of Wilfred Cantwell Smith that

the modern period of Islamic history . . . begins with decadence within, intrusion and menace without; and the worldly glory that reputedly went with obedience to God's law only a distant memory of happier days. ${ }^{21}$

He argues, in an absolute manner, that the West has nothing to do with the "decline" of Islam in the modern world. Modern Islam, in the writer's view, suffers from a fundamental malaise and therefore the only justifiable explanation has to be sought within the Islamic religion.

Nettler proposes that the leaders of modern Islamic resurgence, and in particular Sayyid Qutb, propagated an "emotional hatred which (is) uniquely modern as part of Muslim thinking on the Jews" (p. 51). To him, this supposed Muslim hatred is a metaphysical $a$ priori: it is fixed, absolute, and unchanging, and beyond the rules of history. Nettler does not treat Qutb's ideas in their totality and as a comprehensive dynamic. Instead, he singles out one dimension of his thought: his stand on Zionism and Israel. ${ }^{22}$

To better understand Qutb's ideas, one has to relate them to the influence of foreign powers on the leading members of Egyptian intelligentsia during the 1930 s, 1940s, and 1950s. Early in his professional career as a man of letters in the late $1930 \mathrm{~s}$, Quţb wrote a number of articles on colonialism and westernization, both of which he linked to the British attempt to create a state for the Jews in Palestine. Nettler never refers to these significant phases in the region's history-colonialism and the creation of Israel. Rather, he treats the Qutbian "doctrine of hatred towards the Jews" in an absolute political and historical vacuum.

\footnotetext{
${ }^{20} \mathrm{Many}$ Israeli writers nowadays are propagating this theme. In this regard, see the following major article by the Israeli scholar, Hanna Rahman, "The Conflict between the Prophet and the Opposition in Madina." Der Islam 6, no. 2 (1985): $260-97$.

${ }^{21}$ See W. C. Smith, Islam in Modern History (Princeton: Princeton University Press, 1962), 1 .

${ }^{22}$ For a comprehensive analysis of Sayyid Qutb's ideas on imperialism and Israel, consult the author's study The Intellectual Origins of Islamic Resurgence in the Modern Arab World, to be published by State University of New York Press.
} 
Qutb's philosophy, which is succinctly summarized in his main works Social Justice in Islam ${ }^{23}$ and Islam and the Battle between Islam and Capitalism, ${ }^{24}$ placed him at the center of Egyptian intellectual life during that period. He was never a neutral interpreter of events, but an engaged theologian, philosopher, and social thinker. His social commitments equaled his political and theological concerns. It was quite natural for him, therefore, to respond, analytically at least, to one of the main dangers being faced by the Muslim world: western colonization and its culmination in the creation of Israel. ${ }^{25}$ To a large degree, Qutb's theoretical formulations were shaped by those practical concerns.

It is important at this juncture to stress that a number of wellresearched studies, done mainly in Europe, treat the subject of Islamism in its cultural and theological, and not only political, dimensions. One study is that of Olive Carre's Mystique et politique: lectur revolutionnaire $d u$ Coran par Sayyid Qutb, frere musulmane radical, ${ }^{26}$ which is an indispensable contribution to our understanding of the Qur'anic principles and contents of what has been termed the "Qutbian discourse" (the thoughtstructure of Sayyid Qutb). Carre, who bases her study on a thorough analysis of the principal themes of Sayyid Qutb's major work of exegesis, Fì Ziläl al Qur'ān, ${ }^{27}$ adopts a comparative method of analysis. For instance, he keeps referring to the major exegesis done by the Syrian Rashīd Ridā, ${ }^{28}$ Tafsīr al Manār, and its impact in terms of method and terminology on Qutbian tafsirr. The main difference between Rid̄ā's Tafsìr and Qutb's Ziläl is that Ridā presented a traditional Qur'anic commentary that was in line with traditional Islamic exegesis. Qutb, who

${ }^{23}$ See Sayyid Qutb, al 'Adālah al ljtimā'ìyah fí al Islām (Cairo: 1948?). Translated as Social Justice in Islam (Washington, DC: 1952), by J. Hardy.

${ }^{24}$ Sayyid Qutb, al Ma'rakah bayna al Isläm wa al Ra'smälìyah (Cairo: 1953).

${ }^{25}$ For an elaboration on this theme, see John L. Esposito, Islamic Threat: Myth or Reality? (Oxford: Oxford University Press, 1992).

${ }^{26}$ Olive Carre, Mystique et politique: lectur revolutionnaire du Coran par Sayyid Qutb, frere musulmane radical (Paris: Editions du Cherf, 1984).

${ }^{27}$ Sayyid Qutb, FīZiläl al Qur'ān [In the Shade of the Qur'an] (Beirut: 1974).

${ }^{28} \mathrm{Rida}$ was born in what is now Lebanon. He died in 1937 in Egypt after becoming one of the most influential disciples of Shaykh Mubammad 'Abduh (d. 1905). See Albert Hourani's excellent analysis of part of Ridā's life: Albert Hourani, Islam in European Thought (New York: Oxford University Press, 1991). A recent important book is Emad Eldin Shahin, Through Muslim Eyes: M. Rashìd Ridā and the West (Herndon, VA: The International Institute of Islamic Thought, 1993), especially chapter one. 
came from a secular background of learning, did not follow in the footsteps of traditional exegesis, because he was more effective than Ridā in relating the Qur'anic fact (al haqiquh al Qur'äniyah) ${ }^{29}$ to the exigencies of modern life.

Qutb's main goal, as Carre shows throughout her study, is to free the Qur'anic text from the obscurantism and scholasticism of those 'ulama who emphasize the doctrinal at the expense of the social and the ethical at the expense of the political. Qutb's interpretation is based primarily on philological understanding, the primary social and political situation of the verses (conditions of the revelation), and the present meaning that can be derived from the above. As such, his theoretical reflections gain a new significance: far from restricting himself to philology and past meaning, he is concerned about the relevance of the Qur'anic text to the present.

Carre explains correctly that Qutb's method rests on a number of interdependent principles: theology, philosophy, sociology, politics, and hermeneutics. In addition, experience plays a significant part in his methodological construct. Therefore, the expressions related by Quțb should be understood as part of a whole stream of consciousness emanating from the historical experience of this type of religious figure in a highly diversified intellectual context. Hence Qutb's formula of Qur'anic knowledge is understanding through experience and reflection. We witness the intersection of the personal and the epistemological from his early work and so cannot escape easily from the methodological problematic he construed. He was not objective or subjective: he was pragmatic and idealistic at the same time. His justification was governed by speculative idealism and social pragmatism.

Here, we are concerned with Qutb's theological, social, cultural, and ideological formulations as they appear in the Ziläl. We believe that these formulations are the culmination of mature intellectual reflections that began before he joined the Muslim Brotherhood in 1952. Therefore, Qutb's pre-Ziläl ideas have a direct relevance to what we are trying to study in the Ziläl. In other words, his ouevre has to be considered in its totality before any sound judgement on its value can be reached. What we have in mind is two significant goals: to study his Qur'anic weltanschauung (i.e., the ontology of his thought) and to discuss his basic concepts in relation to the larger issues and problems that have preoccupied

${ }^{29}$ On the elaboration of this term, see Martin Lings, What Is Sufism? (London: Islamic Texts Society, 1993) and his Symbol Archetype: A Study of the Meaning of Existence (London: Quinta Essentia, 1991). 
modem Arabic-Islamic thought: revival, westernization, tradition, the role of the intelligentsia, sacred and profane theories of knowledge, and, in general, the place of religion in the modern world.

In her discussion, Carre argues that "The author, Sayyid Qutb, does not interest us himself. But some elements of his life are uniquely utilized in order to comprehend certain fragments of discourse that make up the Zilal" (p. 19). The Ziläl has furnished the theoretical framework of thinking and behavior for Islamic movements, not only in Egypt but throughout the Arab world and in some [non-Arab] Muslim countries as well. In many passages of the Ziläl, there is clear evidence that Qutb borrowed from the thought of two major Indian Muslim thinkers: Nadwi and Mawdudi.

Carre attempts to lay down the principle themes of the Zilāl: questions of Qutbian method and discourse; the normative foundations of Islamic society; the political form of an Islamic state; questions of peace and war; jāhiliyah vs. Islam; the People of the Book, especially Jews and Christians; the proper Islamic economic system and social structure; the family structure and the role of women in society. One can see readily that the themes of the Ziläl revolve around doctrinal, philosophical, and social issues and questions.

Based on the above theoretical consideration, I would like to investigate, albeit briefly, the main themes and arguments of the modern Islamic discourse, especially that of resurgence. The following are some of the underlying presuppositions and claims of this method:

First: Since the emergence of Islam, the interpretation provided by various scholars of this religious phenomenon has given rise to different discourses. Moreover, within the Arabic language, the words used and the meanings of the words used often change from one discourse to another.

Second: These discourses have been conditioned by the concepts, mental formations, economic conditions, and political attitudes of their particular historical situation. Therefore, in rendering a judgment on somebody's work, one has to pose questions about the historical conditions in which that discourse was produced.

Third: One has to study the different Islamic discourses of modern Islam in relation to the West.

Fourth: The West, as a conceptual category, should be defined both historically and philosophically. 
Fifth: This proposed comprehensive method should elaborate on the possible connection between ideology and discourse. ${ }^{30}$

What is the relationship between modern Islam and the West? Somebody may object to this formulation: how can we equate a theological construct with a purely political or geographic construct? The initial stage of this inquiry, however, is a matter of definition. What is the West? What is Islam?

What is the West? In dealing with the modern West, we have to discuss five salient movements: the Renaissance, the Reformation, the Industrial Revolution (i.e., the process of industrialization), the Enlightenment, and the post-Enlightenment. I want to stress here that these movements are, in essence, philosophical movements. The philosophical underpinnings of the Renaissance were rationalism, humanism, and secularization. The Reformation led to the resurgence of individuality and the annihilation of the communal Christian spirit.

What is Islam? It is impossible, of course, to give a precise linguistic meaning to the term "Islam." For analytical purposes, one could talk of this universal religious phenomenon in the following terms: Islam as metaphysics, Islam as civilization (it means different things to different people), and Islam as the "other."

I would venture to argue that the history of the modern Muslim peoples has been highly intertwined with that of the West. And, therefore, modern Islam cannot be understood except in relation to the modem West and all of the movements that constituted it, be they philosophical, cultural, economic, political, or military. We can delineate three moments or phases in the interaction between modern Islam and the West:

First: The military conquest of Muslim land by the western powers. Muslims were militarily and politically weak. Their only response was to seek refuge in Islam as the reservoir of their strength. This led to the invention or creation of tradition. In addition, the Europeans said that their mission was that of civilizing the pagan Mohammadens.

Second: The translation of European hegemony into a cultural and religious system. This phase is distinguished by the building of western

${ }^{30}$ For an extensive analysis of these ideas, see Ibrahim Abu-Rabi", "Reflections on the Islamic Renaissance in the Modern Arab World: Some Methodological Questions," Islamic Culture, 63, no. 3 (July 1989): 42-59 and "Secularization, Islam and the Future of the Arab World: A Derivative Discourse," Peuples Mediterraneens, no. 60 (JulySeptember 1992), 177-91. 
educational, cultural, and legal institutions that began to replace the traditional Islamic ones. This is the phase of westernization.

Third: Post-colonialism. One distinguishing feature of this is the rise of both nationalism and religious revivalism.

What are the main premises of "resurgent Islam?" The following are some basic characteristics:

First: Islamic resurgence emphasizes the role of reason in Muslim legal theory and calls for a renaissance of Islam in the modern world on the basis of a reactivation of ijtihad in the religious and legal sciences. The Muslims can achieve the ideals of Islam as a religion, as a Shari 'ah, and as a state by opening the door of ijtihad. Furthermore, the neglect of ijtihad caused some Muslims to become ignorant of Islam and others to become attached to westernization and atheism.

Second: Islamic revivalism calls for the reconstruction of the idea of authority, or of the Islamic nation, which involves the gradual "reconstruction of the Muslim ummah" and building a comprehensive system of Islamic law, government, education, and ethics in the modern world. The reconstitution of the ummah in the modern world would be possible if there were a "return" to the original sources of Islam.

Third: It calls for the reconstruction of the sources of knowledge. The Qur'an and the Sunnah are the only sources recognized. The moral, doctrinal, and linguistic superiority of the "grand ancestors" or the Companions of the Prophet furnish the sole criterion by which new ethical and social rules would be judged.

Therefore, Islamic theory of life is characterized by simplicity and doctrinal unity. Many came to define religious reform as a triple unification of doctrine, law, and ethics.

The Muslim Brotherhood was founded in 1928 by Hasan al Bannā. ${ }^{31}$ Bannā, who was greatly influenced by Rid̦ā, acted as a caliph in exile,

${ }^{31}$ On Hasan al Banna see Ishaq Musa al Husaini, The Moslem Brethren: The Greatest of Modern Islamic Movements (Beirut: Khayat's College Book Cooperative, 1954); Charles Wendell, Five Tracts of Hasan al-Banna (Berkeley: University of California Press, 1978); Sa'īd Hawwā, al Madkhal ilä Da'wat al Ikhwān al Muslimīn (Amman: 1979); Ibrāhīm Ghānim, al Fikr al Siyāsī li al Imām Hasan al Bannā (Cairo: 1992), and Rif'at al Sa‘īd, Hasan al Bannā: Kayfa wa Limādhā? (Cairo: 1984). 
the supreme mujtahid of the community, a political and spiritual leader, and the interpreter par excellence of the rules of the Shari'ah.

From its inception, al Bannā's movement sought to find the "Islamic solution" to the problems associated with education, economic organization, and social justice in society. It advocated an Islamic nation that did not feature a separation between religion and state. Next, it proposed an Islamic educational system whose goal was to create the "Muslim individual, the Muslim house, the Muslim nation, and the Muslim government." Third, it created an economic infrastructure based on Islamic principles to solve social injustice.

In the midst of this heritage, so weighty with consequences, the mission of the Ikhwān was to free the Islamic fatherland from all foreign domination and to help a free Islamic state arise in the Islamic fatherland. Bannā considered it the duty of each Muslim to help build such a state, "for as long as this state does not emerge, the Muslims in their totality are committing a sin." In addition, they should work to reform the educational system, wage war against poverty, ignorance, disease, and crime, and create an exemplary society that would deserve to be associated with the Shari'ah.

In conclusion, the above discussion has raised a number of questions that still await answers. One way of passing judgment on the nature, growth, and current dispensation of Islamic resurgence is to study the theological and cultural underpinnings of this phenomena in addition to its political impact.

Ibrahim Abu-Rabi * Professor of Islamic Studies Hartford Seminary Hartford, Connecticut 